\title{
Arsenic trioxide increases expression of secreted frizzled-related protein 1 gene and inhibits the WNT/ $\beta$-catenin signaling pathway in Jurkat cells
}

\author{
YAN WANG ${ }^{1}$, ZUNSONG WANG $^{2}$, HONG LI $^{1}$, WENWEI XU ${ }^{1}$, LIN DONG $^{1}$, \\ YAN GUO $^{1}$, SARAN FENG ${ }^{1}$, KEHONG BI $^{1}$ and CHUANSHENG ZHU ${ }^{1}$ \\ Departments of ${ }^{1}$ Hematology and ${ }^{2}$ Nephrology, \\ Qianfoshan Hospital Affiliated to Shandong University, Jinan, Shandong 250014, P.R. China
}

Received September 18, 2015; Accepted October 19, 2016

DOI: 10.3892/etm.2017.4184

\begin{abstract}
The aim of the present study was to investigate the demethylation effect of arsenic trioxide $\left(\mathrm{As}_{2} \mathrm{O}_{3}\right)$ on the secreted frizzled-related protein 1 (SFRP1) gene and its ability to inhibit the Wingless-type MMTV integration site family (WNT) pathway in Jurkat cells. Methylation-specific polymerase chain reaction was used to examine the $\mathrm{CpG}$ island methylation status of the SFRP1 gene in leukemia cell lines. In addition, the effects on Jurkat cells of treatment with different concentrations of $\mathrm{As}_{2} \mathrm{O}_{3}$ for $48 \mathrm{~h}$ were investigated. Reverse transcription-quantitative polymerase chain reaction was employed to measure the expression of mRNAs, while western blot analysis was used to examine protein expression in cells. The SFRP1 gene was methylated in Jurkat cells. However, both methylated and unmethylated SFRP1 genes were detected in HL60 and K562 cells. In normal bone marrow mononuclear cells, the SFRP1 gene was unmethylated. Following treatment with $\mathrm{As}_{2} \mathrm{O}_{3}$ for $48 \mathrm{~h}$, the SFRP1 gene was demethylated, and the mRNA and protein expression levels of the SFRP1 gene were increased. By contrast, the mRNA and protein expression levels of $\beta$-catenin and cyclin Dl were downregulated. The protein expression of c-myc was also downregulated, but $\mathrm{As}_{2} \mathrm{O}_{3}$ exhibited no significant effect on the mRNA expression of c-myc. Abnormal methylation of the SFRP1 gene was detected in Jurkat cells. These results suggest that $\mathrm{As}_{2} \mathrm{O}_{3}$ activates SFRP1 gene expression at the mRNA and protein levels in Jurkat cells by demethylation of the SFRP1 gene. Furthermore, they indicate that $\mathrm{As}_{2} \mathrm{O}_{3}$ regulates WNT target genes and controls the growth of Jurkat cells through the WNT/ $\beta$-catenin signaling pathway.
\end{abstract}

Correspondence to: Professor Chuansheng Zhu, Department of Hematology, Qianfoshan Hospital Affiliated to Shandong University, 16766 Jingshi Road, Jinan, Shandong 250014, P.R. China E-mail: qfsyywy@163.com

Key words: SFRP1 gene, arsenic trioxide, methylation, leukemia, $\mathrm{WNT} / \beta$-catenin signaling pathway

\section{Introduction}

Aberrant activation of the Wingless-type MMTV integration site family (WNT)/ $\beta$-catenin pathway has been implicated in the pathogenesis of many malignancies (1-3). The phenomenon has also been observed in hematological malignancies $(4,5)$. In addition, abnormal methylation of the promoters of specific $\mathrm{WNT} / \beta$-catenin inhibitors has been reported in leukemia $(6,7)$. The WNT/ $\beta$-catenin signaling pathway plays an important role in the survival, proliferation and differentiation of hematopoietic stem cells. Aberrant activation of $\mathrm{WNT} / \beta$-catenin signaling is closely associated with the pathogenesis of leukemia (8-10). As a result, $\mathrm{WNT} / \beta$-catenin signaling may be an important treatment target for leukemia. The secreted frizzled-related protein (SFRP) family and Dickkopf (DKK) family are WNT signaling antagonists; the WNT/ $\beta$-catenin signaling pathway is regulated tightly by the SFRP and DKK families (11). The functional loss of WNT antagonists contributes to activation of the WNT signaling pathway. Activation of the canonical WNT pathway causes the hypophosphorylation and stabilization of $\beta$-catenin. Following translocation into the nucleus, non-phosphorylated $\beta$-catenin associates with the T-cell factor family of transcription factors, thereby modulating the expression of target genes such as c-myc, cyclin D, matrix metalloproteinase-7 and bone morphogenetic protein-4 (12-15).

Arsenic trioxide $\left(\mathrm{As}_{2} \mathrm{O}_{3}\right)$ is a traditional Chinese medicine. It has been found to be effective in the treatment of malignant hematopoietic diseases by inducing apoptosis and inhibiting cellular proliferation, and has been used to treat acute promyelocytic leukemia and multiple myeloma with good results $(16,17)$. The anticancer effects of $\mathrm{As}_{2} \mathrm{O}_{3}$ are exerted through the induction of apoptosis and differentiation of leukemia cells and reduction of telomerase activity $(18,19)$. However, some studies have found that the metabolism of $\mathrm{As}_{2} \mathrm{O}_{3}$ involves detoxification via methylation, which is similar to the methylation processes of oncogenes and tumor suppressor genes $(20,21)$. In addition, $\mathrm{As}_{2} \mathrm{O}_{3}$ has been reported to utilize S-adenosyl methionine (SAM) (22), an essential co-factor of DNA methyltransferases, which results in DNA hypomethylation. Therefore, $\mathrm{As}_{2} \mathrm{O}_{3}$ may regulate tumor suppressor genes 
by interfering with DNA methylation patterns. Although $\mathrm{As}_{2} \mathrm{O}_{3}$ has been shown to have antileukemic effects, its demethylating and dose-dependent effects on genes associated with other tumors have already been postulated $(20,23)$.

Different molecular mechanisms have been implicated in aberrant activation of the WNT/ $\beta$-catenin signaling pathway. Abnormal methylation of WNT antagonists is a frequent event in several human malignancies $(7,24,25)$. Previous studies have indicated that methylation of SFRP exists in leukemia $(1,2)$. Our previous studies demonstrated that inhibitory factors of the WNT pathway, such as WNT inhibitory factor, DKK1 and SFRP1, are hypermethylated in leukemia cells and patients with leukemia (26-28). $\mathrm{As}_{2} \mathrm{O}_{3}$ has been shown to exert a demethylation effect through the inhibition of DNA methyltransferase, and has a similar demethylation effect to decitabine $(29,30)$. SFRP1 is a member of the SFRP family, and the SFRP1 gene is located on chromosome 8p11.2. As an important inhibitor of the WNT pathway, the SFRP1 gene is involved in the regulation of cell growth and proliferation, and is closely associated with the occurrence of leukemia $(31,32)$. However, it is unclear whether $\mathrm{As}_{2} \mathrm{O}_{3}$ affects the SFRP1 gene, WNT pathway or WNT downstream genes in Jurkat cells. In the present study, the methylation status of the SFRP1 gene in Jurkat cells was examined and the effect of $\mathrm{As}_{2} \mathrm{O}_{3}$ on SFRP1 and the WNT/ $\beta$-catenin signaling pathway was investigated.

\section{Materials and methods}

Cells. Normal bone-marrow mononuclear cells (BMMNCs) and the leukemia cell lines HL60 (acute myeloid leukemia), K562 (chronic myeloid leukemia) and Jurkat (acute T cell leukemia) were purchased from Shandong University Medical School (Shandong, China) and cultured in RPMI-1640 medium supplemented with $10 \%$ fetal bovine serum, $10 \%$ non-essential amino acids, $1 \%$ penicillin and $0.1 \%$ amphotericin $\mathrm{B}$ (Thermo Fisher Scientific, Inc., Waltham, MA, USA). The cells were maintained in an incubator at $37^{\circ} \mathrm{C}$ in an atmosphere with $5 \% \mathrm{CO}_{2}$. Sub-culturing of the cells was performed after $80 \%$ confluence was reached. Cells in the exponential growth phase were treated with $\mathrm{As}_{2} \mathrm{O}_{3}$ (Yida Pharmaceutical Co., Ltd., Harbin, China) at concentrations of $0,1.25,2.5$ and $5.0 \mu \mathrm{mol} / \mathrm{l}$ for $48 \mathrm{~h}$. Untreated cells were used as the control.

DNA extraction and methylation modification. DNA was extracted from the cells using the Wizard Genomic DNA Purification kit (Promega Corporation, Madison, WI, USA) according to manufacturer's protocol. To ensure the purity of the extracted DNA, the ratio of the optical density of the DNA at $260 \mathrm{~nm}$ to that at $280 \mathrm{~nm}$ was confirmed to be $\sim 1.8$. In addition, the DNA concentration was confirmed to be between 0.1 and $0.9 \mathrm{ng} / \mu \mathrm{l}$ using a Smartspec 3000 spectrophotometer (Bio-Rad Laboratories, Inc., Hercules, CA, USA). Approximately $1 \mu \mathrm{g}$ extracted DNA was used for bisulfate modification using the EZ DNA Methylation Gold kit (Zymo Research, Seattle, WA, USA) according to the manufacturer's instructions.

Methylation-specific polymerase chain reaction $(M S P)$. The modified DNA was resuspended in $20 \mu \mathrm{l}$ TE buffer $(10 \mathrm{mM}$ Tris- $\mathrm{HCl}$, and $1 \mathrm{mM}$ EDTA; $\mathrm{pH}=8.0$ ) and immediately subjected to polymerase chain reaction (PCR) or stored at $-20^{\circ} \mathrm{C}$. PCR was performed with Zymo Taq PreMix (Zymo Research) using the primers listed in Table I. Approximately $50 \mathrm{ng}$ bisulfite-modified DNA was amplified by MSP using the following reaction conditions: $95^{\circ} \mathrm{C}$ for $2 \mathrm{~min} ; 95^{\circ} \mathrm{C}$ for $20 \mathrm{sec}, 60^{\circ} \mathrm{C}$ (methylated) or $62^{\circ} \mathrm{C}$ (unmethylated) for $30 \mathrm{sec}$ (40 cycles); and extension at $72^{\circ} \mathrm{C}$ for $7 \mathrm{~min}$. DNA from normal BMMNCs treated with Sss I transmethylase (Zymo Research) was used as a positive control for methylation, and water was used as a negative control. PCR was performed using a PTC-200 cycler (Bio-Rad Laboratories, Inc.). The amplified PCR products $(5 \mu \mathrm{l})$ were analyzed on $2 \%$ agarose gel and visualized under ultra violet illumination. MSP experiments were repeated three times for each sample.

Reverse transcription-quantitative PCR (RT-qPCR). Total RNA was extracted from the cells using TRIzol (Thermo Fisher Scientific, Inc.) according to the manufacturer's instructions. Then, DNase I (Thermo Fisher Scientific, Inc.) treatment was used to remove genomic DNA contamination from the total RNA. RT-qPCR was performed using $0.3 \mu \mathrm{g}$ total RNA following the instructions of the PrimeScript RT reagent kit (\#DRR037A; Takara Biotechnology Co., Ltd., Dalian, China). The reverse transcription system included 5X PrimeScript Buffer $(2 \mu 1)$, PrimeScript RT Enzyme Mix I $(0.5 \mu \mathrm{l})$, oligo dT primer $(0.5 \mu \mathrm{l})$, random 6 mers $(2 \mu \mathrm{l})$, total RNA $(0.3 \mu \mathrm{g})$, and RNase-free $\mathrm{dH}_{2} \mathrm{O}(4.7 \mu \mathrm{l})$. The reaction conditions were as follows: Initial denaturation at $95^{\circ} \mathrm{C}$ for $30 \mathrm{sec}, 40$ cycles of denaturation at $95^{\circ} \mathrm{C}$ for $5 \mathrm{sec}$ and annealing at $60^{\circ} \mathrm{C}$ for $30 \mathrm{sec}$. The PCR amplification system contained cDNA $(2 \mu \mathrm{l}), 10 \mathrm{X}$ buffer $(2 \mu \mathrm{l}), \mathrm{Mg}^{2+}(1 \mu \mathrm{l}), \mathrm{dNTP}$ $(10 \mathrm{mM})(1 \mu \mathrm{l})$, probe $(1 \mu \mathrm{l}$; TaqMan GAPDH detection reagents; Takara Biotechnology Co., Ltd.), Primer-F (1 $\mu$; Table I), Primer-R ( $1 \mu \mathrm{l}$; Table I), $\mathrm{ddH}_{2} \mathrm{O}(10.8 \mu \mathrm{l})$ and Taq DNA polymerase $(0.2 \mu \mathrm{l}$; PrimeScript RT-PCR reagent kit; Takara Biotechnology Co., Ltd.). The reaction system was amplified using an Applied Biosystems 7500 Fast cycler (Thermo Fisher Scientific, Inc.). The reaction conditions were as follows: $95^{\circ} \mathrm{C}$ for $2 \mathrm{~min} ; 94^{\circ} \mathrm{C}$ for $20 \mathrm{sec}$, and $60^{\circ} \mathrm{C}$ for $20 \mathrm{sec}$ (40 cycles); and $72^{\circ} \mathrm{C}$ for $30 \mathrm{sec}$. The experiment was repeated for 3 times. GAPDH was used as internal standard to calculate the relative fold differences using the comparative $\mathrm{Cq}\left(2^{-\Delta \Delta \mathrm{Cq}}\right)$ method (33), and fold differences in SFRP1, $\beta$-catenin, cyclin Dl and c-myc expression compared with untreated cells were determined.

Western blotting. Cells were trypsinized and precooled radioimmunoprecipitation assay lysis buffer $(600 \mu 1 ; 50 \mathrm{mM}$ Tris-base; $1 \mathrm{mM}$ EDTA; $150 \mathrm{mM} \mathrm{NaCl} ; 0.1 \%$ sodium dodecyl sulfate; $1 \%$ Triton X-100; $1 \%$ sodium deoxycholate; Beyotime Institute of Biotechnology, Haimen, China) was added to the samples Following lysis for $50 \mathrm{~min}$ on ice, the mixture was centrifuged at $12,000 \times \mathrm{g}$ and $4^{\circ} \mathrm{C}$ for $5 \mathrm{~min}$. The supernatant was used to determine protein concentration with a bicinchoninic acid protein concentration determination kit [RTP7102; Real-Times (Beijing) Biotechnology Co., Ltd., Beijing, China]. Proteins $(20 \mu \mathrm{g})$ were separated by $12 \%$ sodium dodecyl sulfate polyacrylamide gel electrophoresis under reducing conditions and transferred to nitrocellulose membranes (Whatman; GE Healthcare Bio-Sciences, 
Table I. Primer sequences.

Genes

Primer sequences

SFRP1

SFRP1 (methylated)

SFRP1 (unmethylated)

$\beta$-catenin

Cyclin Dl

c-myc

GAPDH
Forward: 5'-TTGAGCATTTGAAAGGTGTGCTA-3'

Reverse: 5'-ACAGCTACACTACCAGGGAAATCC-3'

Forward: 5'-GCGTTGGGTATTTAGTAGGATTTATTCG-3' Reverse: 5'-CGAACCCAACAGATCCCACGA-3'

Forward: 5'-GTGTTTGGTATTCAGTAGGATTTATTTG-3' Reverse: 5'-CAAACCCAAACAATCCCACAAC-3'

Forward: 5'- ATCCCACTGGCCTCTGATAAAG-3'

Reverse: 5'-GTACGGCGCTGGGTATCCT-3'

Forward: 5'-CGTGGCCTCTAAGATGAAGGA-3'

Reverse: 5'-TCGGTGTAGATGCACAGCTTCT-3'

Forward: 5'-TGAATCTGCCGCAGCTAGAA-3'

Reverse: 5'- TCCCCTCGTTGCTCTTGTTC-3'

Forward: 5'-AGAAGGCTGGGGCTCATTTG-3'

Reverse: 5'-AGGGGCCATCCACAGTCTTC-3'

SFRP1, secreted frizzled-related protein 1.

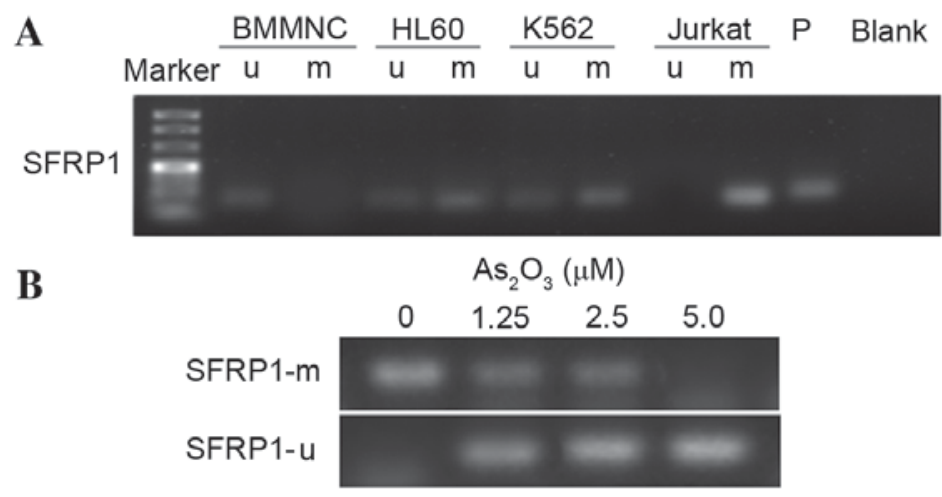

Figure 1. Methylation-specific polymerase chain reaction analysis of (A) SFRP1 gene expression in normal BMMNCs and leukemia cell lines (HL60, K562 and Jurkat). (B) SFRP1 gene expression in Jurkat cells treated with $\mathrm{As}_{2} \mathrm{O}_{3}$ at different concentrations $(0,1.25,2.5$ and 5.0 $\mu \mathrm{M})$ for $48 \mathrm{~h}$. BMMNC, normal bone marrow mononuclear cell; P, positive control; u, unmethylated; m, methylated; SFRP1, secreted frizzled-related protein 1.

Pittsburgh, PA, USA). The membranes were incubated with phosphate-buffered saline containing $0.1 \%$ Tween-20 and 5\% non-fat dry milk to block nonspecific binding. The membranes were then incubated for $1.5 \mathrm{~h}$ with rabbit anti-human SFRP1 $(1: 1,000 ; \# 4690), \beta$-catenin $(1: 1,000 ; \# 8480)$, cyclin D1 (1:1,000; \#2978), c-myc (1:1,000; \#5605; all Cell Signaling Technology, Inc., Danvers, MA, USA) and $\beta$-actin antibodies (1:1,000; \#8227; Abcam, Cambridge, UK), followed by $1 \mathrm{~h}$ incubation with horseradish peroxidase-conjugated goat anti-rabbit immunoglobulin $\mathrm{G}$ secondary antibody (1:10,000; \#111-005-045; Jackson ImmunoResearch Laboratories, Inc., West Grove, PA, USA). Signals were visualized using an enhanced chemiluminescence detection system (ChemiDoc-It System; UVP, Inc., Upland, CA, USA). The intensity of protein fragments was quantified using Basic Quantity One software (v4.5.0; Bio-Rad Laboratories, Inc.). The relative expression of each protein was normalized to $\beta$-actin control.
Statistical analysis. Data are expressed as the mean \pm standard deviations. Comparisons were made using an independent samples t-test with SPSS software (version 16.0; SPSS, Inc., Chicago, IL, USA). $\mathrm{P}<0.05$ was considered to indicate a statistically significant result.

\section{Results}

$\mathrm{As}_{2} \mathrm{O}_{3}$ induces demethylation of the CpG islands of SFRPI in Jurkat cells. To test the effect of different concentrations of $\mathrm{As}_{2} \mathrm{O}_{3}$ on the methylation status of DNA, MSP analysis was performed. DNA from normal BMMNCs treated with SssI transmethylase was used as a positive control for methylation, DNA from BMMNCs of healthy controls served as negative control, and water was used as a blank control. The data showed that the SFRP1 gene promoter was completely methylated in Jurkat cells, partially methylated in HL60 and K562 cells, and unmethylated in normal bone marrow mononuclear 
A

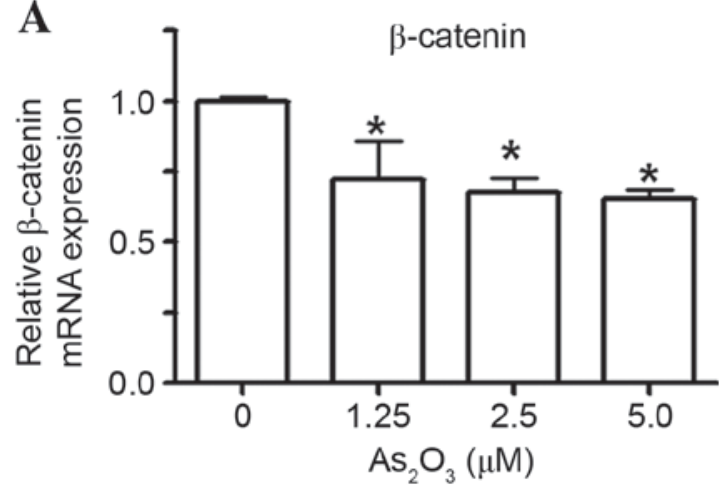

C

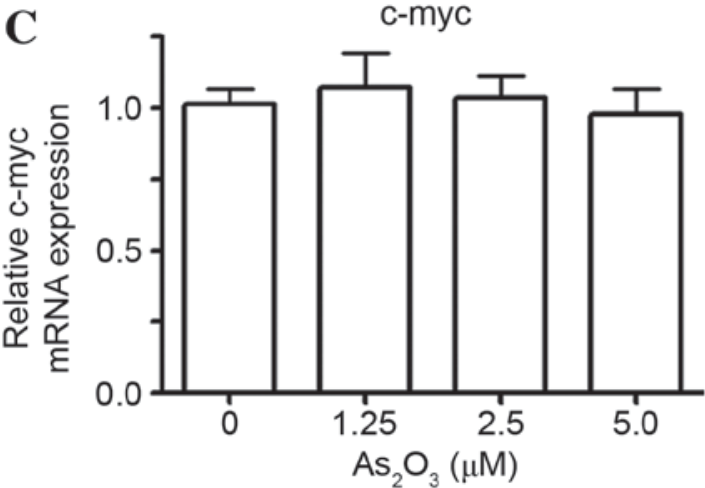

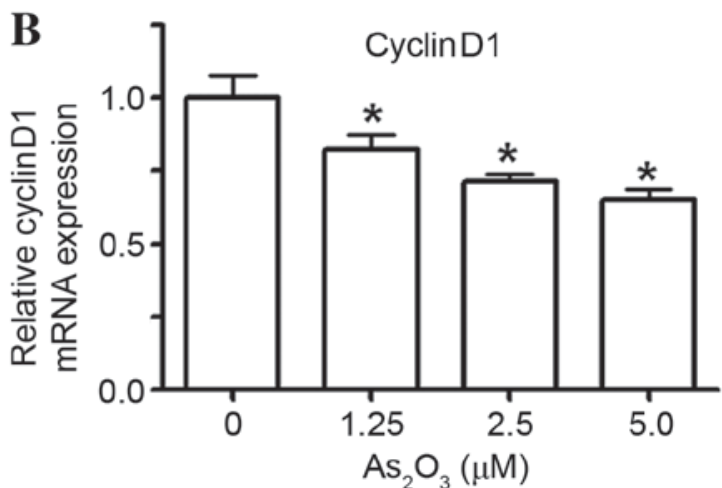

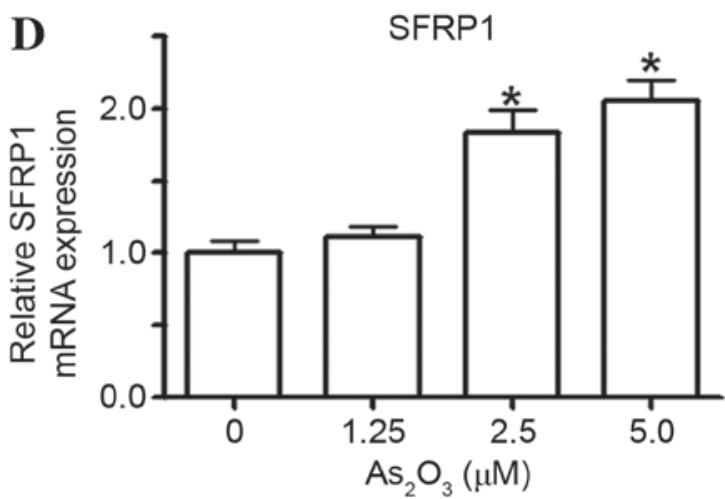

Figure 2. Expression of (A) $\beta$-catenin, (B) cyclin D1, (C) c-myc and (D) SFRP1 mRNA in Jurkat cells treated with 0, $1.25,2.5$ and 5.0 $\mu$ M As $\mathrm{O}_{3}$. Reverse transcription-quantitative polymerase chain reaction was performed to measure mRNA expression. Data are expressed as the mean $\pm \mathrm{SD}$ ( $\mathrm{n}=3-6$ ). ${ }^{*} \mathrm{P}<0.05$ vs. $0 \mu \mathrm{M} \mathrm{As}_{2} \mathrm{O}_{3}$. SFRP1, secreted frizzled-related protein 1.
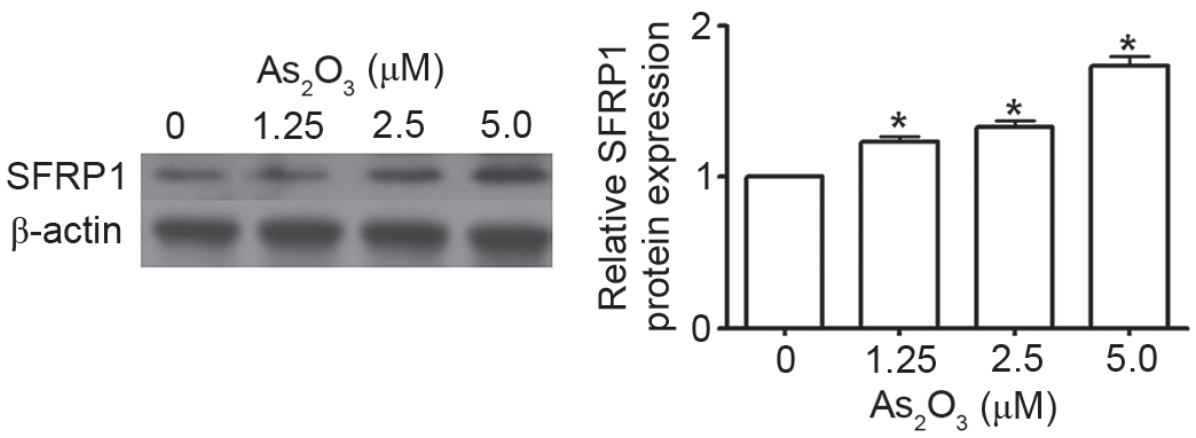

Figure 3. Western blot analysis of SFRP1 protein expression in Jurkat cells treated with $0,1.25,2.5$ and $5.0 \mu \mathrm{M}$ As $\mathrm{O}_{3}$. Data are expressed as the mean \pm SD (n=3-6). ${ }^{*} \mathrm{P}<0.05$ vs. $0 \mu \mathrm{M} \mathrm{As} \mathrm{O}_{3}$. SFRP1, secreted frizzled-related protein 1.

cells (Fig. 1A). In addition, the methylation-specific bands of the SFRP1 gene were significantly decreased in Jurkat cells treated with 1.25, 2.5 and $5.0 \mu \mathrm{mol} / 1 \mathrm{As}_{2} \mathrm{O}_{3}$ for $48 \mathrm{~h}$. By contrast, the non-methylation-specific bands of SFRP1 genes were significantly increased in Jurkat cells treated with 1.25, 2.5 and $5.0 \mu \mathrm{mol} / 1 \mathrm{As}_{2} \mathrm{O}_{3}$ for $48 \mathrm{~h}$. Notably, the attenuation of the hypermethylation of SFRP1 by $\mathrm{As}_{2} \mathrm{O}_{3}$ was not dose-dependent in Jurkat cells (Fig. 1B). These results suggest that $\mathrm{As}_{2} \mathrm{O}_{3}$ induces the demethylation of $\mathrm{CpG}$ islands of SFRP1 in Jurkat cells.

$\mathrm{As}_{2} \mathrm{O}_{3}$ increases the mRNA expression level of SFRPI in Jurkat cells. To study the effect of $\mathrm{As}_{2} \mathrm{O}_{3}$ on SFRP1, $\beta$-catenin, cyclin Dl and c-myc mRNA expression in Jurkat cells, RT-qPCR was employed. $\mathrm{As}_{2} \mathrm{O}_{3}$ decreased the expression levels of $\beta$-catenin (Fig. 2A) and cyclin Dl (Fig. 2B) in a dose-dependent manner $(\mathrm{P}<0.05)$, but had no effect on the expression of $\mathrm{c}-\mathrm{myc}$ mRNA (P>0.05; Fig. 2C). Notably, SFRP1 mRNA expression in Jurkat cells was increased in a dose-dependent manner by treatment with increasing concentrations of $\mathrm{As}_{2} \mathrm{O}_{3}$ for $48 \mathrm{~h}$; the increases resulting from treatment with 2.5 and $5.0 \mu \mathrm{mol} / 1$ were significant $(\mathrm{P}<0.05$; Fig. 2D). These results indicate that $\mathrm{As}_{2} \mathrm{O}_{3}$ increases the mRNA expression level of SFRP1 in Jurkat cells.

$\mathrm{As}_{2} \mathrm{O}_{3}$ increases SFRP1 protein expression, but decreases $\beta$-catenin, cyclin $D l$ and $c$-myc protein expression levels in Jurkat cells. To determine the effect of $\mathrm{As}_{2} \mathrm{O}_{3}$ on the protein expression of SFRP1, $\beta$-catenin, cyclin Dl and c-myc, western blotting was conducted. Western blots showed 
A

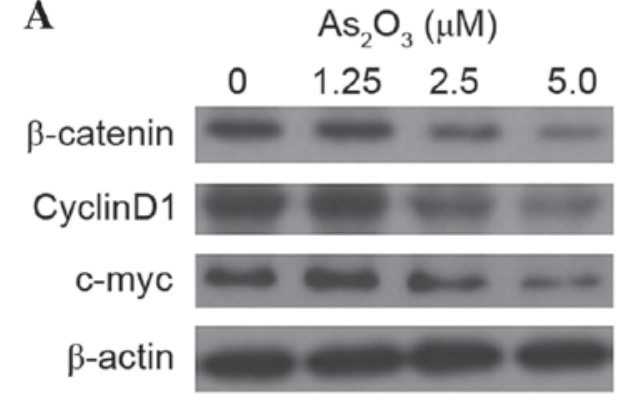

C

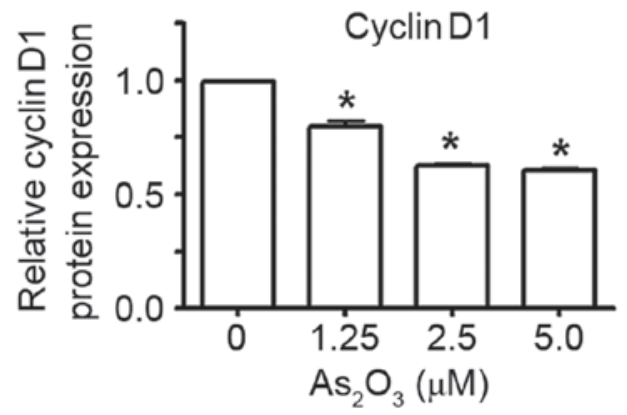

B

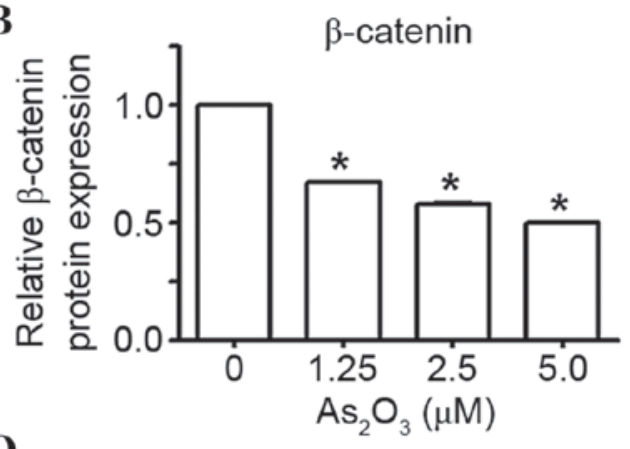

D

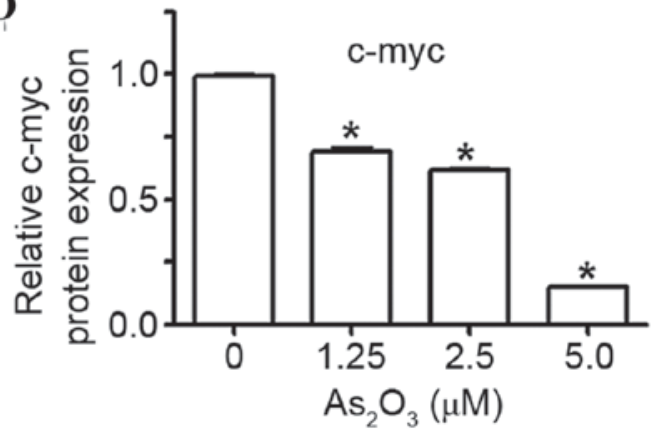

Figure 4. Western blot analysis of proteins in Jurkat cells treated with 0, 1.25, 2.5 and 5.0 $\mu \mathrm{M} \mathrm{As}_{2} \mathrm{O}_{3}$. (A) Representative western blots and expression levels of (B) $\beta$-catenin, (C) cyclin Dl and (D) c-myc proteins. Data are expressed as the mean $\pm \mathrm{SD}(\mathrm{n}=3-6){ }^{*} \mathrm{P}<0.05 \mathrm{vs} .0 \mu \mathrm{M} \mathrm{As}_{2} \mathrm{O}_{3}$.

that $\mathrm{As}_{2} \mathrm{O}_{3}$ increased the protein expression of SFRP1 in a dose-dependent manner $\left(\mathrm{P}<0.05\right.$; Fig. 3). However, $\mathrm{As}_{2} \mathrm{O}_{3}$ decreased the protein expression of $\beta$-catenin, cyclin Dl and $\mathrm{c}$-myc in a dose-dependent manner $(\mathrm{P}<0.05$; Fig. 4). These results suggest that $\mathrm{As}_{2} \mathrm{O}_{3}$ increases SFRP1 protein expression, but decreases $\beta$-catenin, cyclin D1 and c-myc protein expression in Jurkat cells.

\section{Discussion}

The results of the present study indicate that $\mathrm{As}_{2} \mathrm{O}_{3}$ induces the demethylation of SFRP1 genes in Jurkat cells, and upregulates SFRP1 gene expression at the mRNA and protein levels. However, the demethylation effect of $\mathrm{As}_{2} \mathrm{O}_{3}$ was not found to be completely dose-dependent, which conflicts with previous studies $(34,35)$. This observation may be due to differences in the leukemia cell lines used and genes analyzed. This suggests that the different types of leukemia may have different pathogeneses. The mechanism of action of $\mathrm{As}_{2} \mathrm{O}_{3}$ also appears to also differ among leukemia cell lines.

$\beta$-catenin is an important component of the WNT pathway, and reflects the activity of the WNT pathway (36). In the present study, following treatment with $\mathrm{As}_{2} \mathrm{O}_{3}$ the expression of $\beta$-catenin mRNA and protein was significantly reduced, suggesting that $\mathrm{As}_{2} \mathrm{O}_{3}$ affects the activity of the WNT pathway. Cyclin Dl, c-myc and B-cell lymphoma-2 (Bcl-2) are downstream genes of the WNT pathway, and play important roles in cell proliferation, differentiation and apoptosis (37). Cyclin D1 positively regulates cell cycle, and facilitates cells to cross $\mathrm{G} 1 / \mathrm{S}$ check point to enter $\mathrm{S}$ phase. Cyclin D1 is overexpressed in multiple tumors (13). $\mathrm{As}_{2} \mathrm{O}_{3}$ arrests some tumor cells at G1 phase and inhibits tumor cell proliferation (38). In the present study, RT-qPCR and western blotting demonstrated that $\mathrm{As}_{2} \mathrm{O}_{3}$ treatment reduced cyclin D1 expression in Jurkat cells. Therefore, $\mathrm{As}_{2} \mathrm{O}_{3}$ has an anti-leukemia effect by inhibiting the proliferation of Jurkat cells via the down-regulation of cyclin D1 expression. In the present study, the expression of c-myc mRNA was not significantly altered, but the expression of c-myc protein was downregulated. The inconsistency between mRNA and protein expression may be due to the fact that mRNA is affected by a number of molecular regulatory factors, such as by microRNA, or it may be possible that post-translational regulation serves a role. Gene regulation in the cell cycle is complex, and multiple genes may be associated with the same protein (39). The regulatory effect of $\mathrm{As}_{2} \mathrm{O}_{3}$ on B-cell lymphoma-2 has been extensively studied (40), and so was not examined in the present study.

To summarize, the results of the present study indicate that $\mathrm{As}_{2} \mathrm{O}_{3}$ increases the expression of the WNT suppressor gene SFRP1 by demethylation, and reduces the expression of $\beta$-catenin, thereby inhibiting the WNT pathway through downregulation of the expression of the WNT downstream target genes cyclin Dl and c-myc. The demethylation effect of $\mathrm{As}_{2} \mathrm{O}_{3}$ in leukemia cell lines suggests the potential of $\mathrm{As}_{2} \mathrm{O}_{3}$ as a demethylation drug that could be widely used in the treatment of leukemia. However, the methylation effects of $\mathrm{As}_{2} \mathrm{O}_{3}$ on other important genes are worthy of further study.

\section{Acknowledgements}

This study was supported by Natural Science Foundation of Shandong Province (grant no. ZR-2012HL06), Shandong Province Science and Technology Plans (grant no. 2014GSF118029) and Shandong Medical and Health Science and Technology Development Plan (grant no. 2014WS0105). 


\section{References}

1. Xu CB, Shen JZ, Shen SF, Fu HY, Zhu YF and Chen L: The significance of methylation status of secreted frizzled related protein gene promoter in acute leukemia. Zhonghua Nei Ke Za Zhi 49: 769-771, 2010 (In Chinese).

2. Griffiths EA, Gore SD, Hooker C, McDevitt MA, Karp JE, Smith BD, Mohammad HP, Ye Y, Herman JG and Carraway HE: Acute myeloid leukemia is characterized by Wnt pathway inhibitor promoter hypermethylation. Leuk Lyrephoma 51: 1711-1719, 2010.

3. Bai XL, Zhang Q, Ye LY, Liang F, Sun X, Chen Y, Hu QD, $\mathrm{Fu} \mathrm{QH}, \mathrm{Su} \mathrm{W}$, Chen Z, et al: Myocyte enhancer factor $2 \mathrm{C}$ regulation of hepatocellular carcinoma via vascular endothelial growth factor and $\mathrm{Wnt} / \beta$-catenin signaling. Oncogene 34 4089-4097, 2015

4. Kaveri D, Kastner P, Dembélé D, Nerlov C, Chan S and Kirstetter P: $\beta$-Catenin activation synergizes with Pten loss and Myc overexpression in Notch-independent T-ALL. Blood 122: 694-704, 2013

5. Shuai X, Zhou D, Shen T, Wu Y, Zhang J, Wang X and Li Q: Overexpression of the novel oncogene SALL4 and activation of the Wnt/beta-catenin pathway in myelodysplastic syndromes. Cancer Genet Cytogenet 194: 119-124, 2009.

6. Valencia A, Román-Gómez J, Cervera J, Such E, Barragán E, Bolufer P, Moscardó F, Sanz GF and Sanz MA: Wnt signaling pathway is epigenetically regulated by methylation of Wnt antagonists inacute myeloid leukemia. Leukemia 23: 1658-1666, 2009 .

7. Román-Gómez J, Cordeu L, Agirre X, Jiménez-Velasco A, San José-Eneriz E, Garate L, Calasanz MJ, Heiniger A, Torres A and Prosper F: Epigenetic regulation of Wnt-signaling pathway in acute lymphoblastic leukemia. Blood 109: 3462-3469, 2007.

8. Ge X and Wang X: Role of Wnt canonical pathway in hematological malignancies. J Hematol Oncol 3: 33, 2010.

9. Reya T, Duncan AW, Ailles L, Domen J, Scherer DC, Willert K, Hintz L, Nusse R and Weissman IL: A role for Wnt signalling in self-renewal of haematopoietic stem cells. Nature 423: 409-414, 2003.

10. Weerkamp F, van Dongen JJ and Staal FJ: Notch and Wnt signaling in T-lymphocyte development and acute lymphoblastic leukemia. Leukemia 20: 1197-1205, 2006.

11. Kawano Y and Kypta R: Secreted antagonists of the Wnt signaling pathway. J Cell Sci 116: 2627-2634, 2003.

12. Wodarz A and Nusse R: Mechanisms of Wnt signaling in development. Ann Rev Cell Dev Biol 14: 59-88, 1998.

13. Wang HL, Wang J, Xiao SY, Haydon R, Stoiber D, He TC, Bissonnette $\mathrm{M}$ and Hart J: Elevated protein expression of cyclin Di and Fra-I but decreased expression of c-Myc in human colorectal adenoclu'cinomas overexpressing beta-catenin. Int J Cancer 101: 301-310, 2002.

14. Cadigan KM and Liu YI: Wnt signaling: Complexity at the surface. J Cell Sci 119: 395-402, 2006.

15. Pan FY, Zhang SZ, Xu N, Meng FL, Zhang HX, Xue B, Han X and Li CJ: Beta-catenin signaling involves HGF-enhanced HepG2 scattering through activating MMP-7 transcription. Histochem Cell Biol 134: 285-295, 2010.

16. Shen ZX, Chen GQ, Ni JH, Li XS, Xiong SM, Qiu QY, Zhu J, Tang W, Sun GL, Yang KQ, et al: Use of arsenic trioxide (As2O3) in the treatment of acute promyelocytic leukemia (APL): II Clinical efficacy and pharmacokinetics in relapsed patients. Blood 89: 3354-3360, 1997.

17. Berenson JR, Matous J, Swift RA, Mapes R, Morrison B and Yeh HS: A phase I/II study of arsenic trioxide/bortezomib/ascorbic acid combination therapy for the treatment of relapsed or refractory multiple myeloma. Clin Cancer Res 13: 1762-1768, 2007.

18. Zhao WL, Chen SJ, Shen Y, Xu L, Cai X, Chen GQ, Shen ZX, Chen $\mathrm{Z}$ and Wang ZY: Treatment of acute promyelocytic leukemia with arsenic trioxide: Clinical and basic studies. Leuk Lymphoma 42: 1265-1273, 2001.

19. Tarkanyi I, Dudognon C, Hillion J, Pendino F, Lanotte M, Aradi J and Ségal-Bendirdjian E: Retinoid/arsenic combination therapy of promyelocytic leukemia: Induction of telomerase-dependent cell death. Leukemia 19: 1806-1811, 2005.
20. Du J, Zhou N, Liu H, Jiang F, Wang Y, Hu C, Qi H, Zhong C, Wang $X$ and Li Z: Arsenic induces functional reexpression of estrogen receptor $\alpha$ by demethylation of DNA in estrogen receptor-negative human breast cancer. PLoS One 7: e35957, 2012.

21. Xia J, Li Y, Yang Q, Mei C, Chen Z, Bao B, Ahmad A, Miele L, Sarkar FH and Wang Z: Arsenic trioxide inhibits cell growth and induces apoptosis through inactivation of notch signaling pathway in breast cancer. Int J Mol Sci 13: 9627-9641, 2012.

22. Thomas DJ, Nava GM, Cai SY, Boyer JL, Hernández-Zavala A and Gaskins HR: Arsenic (+ 3 oxidation state) methyltransferase and the methylation of arsenicals in the invertebrate chordate Ciona intestinalis. Toxicol Sci 113: 70-76, 2010.

23. Ji H, Li Y, Jiang F, Wang X, Zhang J, Shen J and Yang X: Inhibition of transforming growth factor beta/SMAD signal by MiR-155 is involved in arsenic trioxide-induced anti-angiogenesis in prostate cancer. Cancer Sci 105: 1541-1549, 2014.

24. Liu TH, Raval A, Chen SS, Matkovic JJ, Byrd JC and Plass C: CpG island methylation and expression of the secreted frizzled-related protein gene family in chronic lymphocytic leukemia. Cancer Res 66: 653-658, 2006.

25. Chim CS, Chan WW, Pang A and Kwong YL: Preferential methylation of Wnt inhibitory factor-1 in acute promyelocytic leukemia: An independent poor prognostic factor. Leukemia 20: 907-909, 2006

26. Wang Y, Zhu XX and Zhu CS: Abnormal methylation patterns of SFRP1 gene in cells of leukemia and inhibition of arsenic trioxide on the SFRP1 gene. Zhonghua Xue Ye Xue Za Zhi 34: 157-159, 2013 (In Chinese).

27. Wang Y, Zhu CS, Bi KH, Xu WW, Dong L and Hou M: Study of WIF-1 promoter methylation with expressions of $\beta$-catenin in acute leukemia. Zhonghua Yi Xue Za Zhi 91: 2858-2860, 2011 (In Chinese).

28. Zhu XX, Zhu CS, Wang Y, Xu WW, Dong L, Guo Y, Li H and Bi KH: Analysis of methylation of the Dickkopf1 (DKK-1) gene in acute leukemia. Journal of Shandong University (Health Sciences) 50: 84-87, 2012.

29. Li H, Wang Y, Xu W, Dong L, Guo Y, Bi K and Zhu C: Arsenic trioxide inhibits DNA methyltransferase and restores TMS1 gene expression in K562 cells. Acta Haematol 133: 18-25, 2014

30. Fu HY, Shen JZ, Wu Y, Shen SF, Zhou HR and Fan LP: Arsenic trioxide inhibits DNA methyltransferase and restores expression of methylation-silenced CDKN2B/CDKN2A genes in human hematologic malignant cells. Oncol Rep 24: 335-343, 2010.

31. Nusse R and Varmus HE: Wnt genes. Cell 69: 1073-1087, 1992.

32. Shen JZ, Xu CB, Fu HY, Wu DS, Zhou HR and Fan LP: Methylation of secreted frizzled related protein gene in acute leukemia patients in China. Asian Pac J Cancer Prev 12: 2617-2621, 2011.

33. Livak KJ and Schmittgen TD: Analysis of relative gene expression data using real-time quantitative PCR and the 2(-Delta Delta C(T)) Method. Methods 25: 402-408, 2001.

34. Meng Z, Wang DM, Li YH, Liu X, Guo SQ and Luo JM: Demethylation effect of inhibitor As2O3 on expression of SHP-1 and C-kit genes in leukemia HL-60 cells. Zhongguo Shi Yan Xue Ye Xue Za Zhi 21: 613-616, 2013 (In Chinese).

35. Zhang XK, Luo JM and Sun J: Effect of arsenic trioxide and 5-aza-2'-deoxycytidine on SHP-1, JAK3, TYK2 gene expression in K562 cells. Zhongguo Shi Yan Xue Ye Xue Za Zhi 22: 323-328, 2014 (In Chinese).

36. Cadigan KM: Wnt-beta-catenin signaling. Curr Biol 18: R943-R947, 2008

37. Karim R, Tse G, Putti T, Scolyer R and Lee S: The significance of the Wnt pathway in the pathology of human cancers. Pathology 36: 120-128, 2004.

38. Zhang X, Jia S, Yang S, Yang Y, Yang T and Yang Y: Arsenic trioxide induces $\mathrm{G} 2 / \mathrm{M}$ arrest in hepatocellular carcinoma cells by increasing the tumor suppressor FTEN expression. J Cell Biochem 113: 3528-3535, 2012.

39. Feala JD, Cortes J, Duxbury PM, McCulloch AD, Piermarocchi $\mathrm{C}$ and Paternostro G: Statistical properties and robustness of biological controller-target networks. PLoS One 7: e29374, 2012.

40. Dong X, Ma N, Liu M and Liu Z: Effects of $\mathrm{As}_{2} \mathrm{O}_{3}$ nanoparticles on cell growth and apoptosis of NB4 cells. Exp Ther Med 10: 1271-1276, 2015 . 